Portland State University

PDXScholar

$9-27-1973$

\title{
Characteristics of Arginase from the Terebellid Polychaete Pista pacifica Berkeley
}

Karen Laurel O'Malley

Portland State University

Follow this and additional works at: https://pdxscholar.library.pdx.edu/open_access_etds

Part of the Biology Commons

Let us know how access to this document benefits you.

\section{Recommended Citation}

O'Malley, Karen Laurel, "Characteristics of Arginase from the Terebellid Polychaete Pista pacifica Berkeley" (1973). Dissertations and Theses. Paper 1660.

https://doi.org/10.15760/etd.1659

This Thesis is brought to you for free and open access. It has been accepted for inclusion in Dissertations and Theses by an authorized administrator of PDXScholar. Please contact us if we can make this document more accessible: pdxscholar@pdx.edu. 
AN ABSTRACT OF THE THESIS OF Karen Laurel O'Malley for the Master of Science in Biology presented September 27, 1973.

Title: Characteristics of Arginase from the Terebellid Polychaete Pista pacifica Berkeley.

APPROVED BY MEMBERS OF THE THESIS COMMITTEE:

Leonard Simpson, Chairman

Robert C. Terwilliger

Joann Loehr

Arginase has been found to occur in the tentacles, gut, and body wall of Pista pacifica Berkeley. Partially purified arginase from the Intestine has a molecular welght of 200,000 , a $\mathrm{Km}$ of about $155 \mathrm{mM}$, an arginase/canavanase ratio of 22 , a $\mathrm{pH}$ optimum of 10.5 , and a temperature optimum of $60^{\circ} \mathrm{C}$. In addition, $\underline{p}$. pactfica arginase is competitively inhibited by ornithine but is not inhibited by high arginine concentrations, nor by sulfhydryl reagents. The enzyme is not stimulated by exogenous manganese and breaks down into an active subunit under harsh treatment. The subunit has a $\mathrm{km}$ of about $118 \mathrm{mM}$ and is also unaffected by exogenous manganese. 
Polychaete arginase shows most of the properties characteristic of arginases from other animal and plant species. However, none of the characteristics observed to date can be correlated with a particular mode of nitrotelism. 


\section{CHARACTERISTICS OF ARGINASE FROM THE TEREBELLID \\ POLYCHAETE Pista pacifica Berkeley}

by

KAREN LAUREL O'MALLEY

A thesis submitted in partial fulfillment of the requirements for the degree of

\section{MASTER OF SCIENCE \\ in \\ BIOLOGY}

Portland State University

1973 
TO THE OFFICE OF GRADUATE STUDIES AND RESEARCH:

The members of the Committee approve the thesis of

Karen Laure1 0'Malley presented September 27, 1973.

Leonard Simpson

Robert C. Terwilliger

J

Jøann Loehr

APPROVED :

Earl Fisher, Jr., Head, Department of Biology

David T. Clark, Dean of Graduate Studies and Research 
TABLE OF CONTENTS

PAGE

APPROVAL PAGE. ..................... Ii

LIST OF TABLES . . . . . . . . . . . . . . . . . . v

LIST OF FIGURES. . . . . . . . . . . . . . . . . vi v vi

PRIMARY DIVISION

I INTRODUCTION. . . . . . . . . . . 1

II METHODS AND MATERIALS . . . . . . . . 3

Enzyme Source and Assay ....... . 3

Molecular Weight. . . . . . . . 4

Polyacrylamide Gel Electrophoresis. . . 4

Sterile Sea Water......... . 4

Reagents. . . . . . . . . 5

III RESULTS . . . . . . . . . . 6

Purification of Pista pacifica Arginase 6

Distribution of Arginase. . . . . 10

pH Optimum. . . . . . . . . . . 11

Effect of Temperature . . . . . . 11

Substrate Kinetics. . . . . . . 14

Effect of $\mathrm{Mn}^{2+}$ Concentration. . . . 14

Specificity . . . . . . . . . 14 
Effect of Sulfhydry l. Compounds . . . 17

Molecular Weight . . . . . . 18

Appearance of an Active Subunit. . . 18

Polyacrylamide Gel Electrophoresis

of Subunit .......... 22

Michaelis Constant of Subunit. . . . 22

Effect of $\mathrm{Mn}^{2}+$ Concentration on

the Subunit. . . . . . . . 22

IV DISCUSSION

26

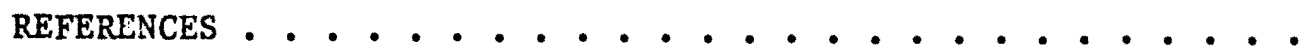




\section{LIST OF TABLES}

TABLE

PAGE

I Purification of Pista pacifica Arginase . . . . . 7

II Distribution of Arginase in the Tissues of Pista

pacifica. . . . . . . . . . . . .

III Distribution of Arginase in the Tissues of Pista pacifica Maintained in Sterile Sea Water for 72 Hours. . . . . . . . . . . .

IV The Effect of $\mathrm{Mn}^{2+}$ Concentration on Pista pacifica Arginase Activity .............

V Substrate Specificity of Pista pacifica Arginase. .

VI The Effect of Sulfhydryl Compounds on Pista pacifica Arginase . . . . . . . . . .

VII Effect of $\mathrm{Mn}^{2+}$ Concentration on Pista pacifica

Subunit Activity. . . . . . . . . . .

VIII Characteristics of Arginase in Relation to 


\section{LIST OF FIGURES}

FIGURE

PAGE

1 DEAE-Cellulose Chromatographic Fractionation

of P. pacifica Arginase After Ethanol

Fractionation .............. 8

2 Sephadex G-200 Gel Filtration of Polychaete Argin-

ase After DEAE-Cellulose Chromatography . . . . 9

3 pH Optimum of Pista pacifica Arginase . . . . . . 12

4 The Effect of Temperature on $\underline{P}$. pacifica Arginase . . 13

5 Plot of $\log \mathrm{V}$ versus $1 / \mathrm{T}$............. 13

6 Kinetic Behavior of $\underline{P}$. pacifica Arginase. . . . . . 15

7 Hill Plot of Pista pacifica Arginase Kinetics . . . 16

8 Estimate of Molecular Weight of Pista pacifica

Arginase. . . . . . . . . . . . 20

9 Breakdown of $\underline{P}$. pacifica Arginase After Acetone

Fractionation .............. 21

10 Appearance of Subunit on Sephadex G-200 . . . . . . 23

11 Lineweaver-Burke Plot of Affintty of Subunit

for Substrate . . . . . . . . . . 


\section{INTRODUCTION}

The terebellid polychaete Pista pacifica is commonly found in sandy mud flats of relatively protected areas such as bays or estuaries. These terbellid worms are easily located by the top of their tube, an elaborately shaped hood which lies on the surface of the mud, presumably protecting the animal from predation or clogging of the tube by debris. The tubes, composed of mucous, sand and mud, extend vertically $70-80$ $\mathrm{cm}$ into the substrate and are closed at the end by a small plug of sand with holes resembling a button. The worm comes to the top of the tube to feed by extending its long white tentacles out over the surface mud. Nutrients are sent back to the mouth by means of a ciliated groove along each tentacle. Defecation is accomplished by reversing positions in the tube so that the anus is projected outside. Other inhabitants of the tube include the scale worm Halosydna brevisetosa and large colonies of the bryozoan Tritecella elongata which live on the inner tube surfaces and on the body wall of Pista itself.

Evidence is presented in this paper for the presence of an arginase in the tentacles, gut tissues, and body wall of Pista pacifica. Larginase (L-arginine ureohydrolase. E.C. 3.5.3.1.) catalyzes the hydro1ysis of L-arginine into L-ornithine and urea. This enzyme once thought to be present only in ureotelic species (Clementi, 1937) now appears to be widespread throughout the animal kingdom. Characterization data have been reported for an oligochaete annelid (Bishop \& Campbe11, 1965: Reddy \& Campbe11, 1968), a crayfish (Hartenstein, 1971), a mollusc (Camp- 
be11, 1966), insects (Reddy \& Campbel1, 1969a), amphibians (Soberón et al., 1967; Carlisky \& Sadnik, 1972), reptiles and birds (Mora et al., 1965; Brown, 1966), and mammals (Greenberg, 1960; Hirsch-Kolb et al., 1970).

Several research groups have reported significant differences in arginases from ureotelic, uricotelic, and ammonotelic organisms with respect to antigenic properties, molecular weights, Michaelis constants, substrate inhibition, and stability during dialysis (Mora et al., 1965, 1966; Soru, 1965; Brown, 1966; Soberón, et al., 1967; Reddy \& Campbe11, 1968, 1969a; Rossi \& Graz1, 1969; Middlehoven, 1969; Hirsch-Kolb et al., 1970). However, more recent studies (Reddy \& Campbel1, 1970;

Hartenstein, 1971) contradict the hypothesis of a distinction between a species' mode of nitrogen excretion and its arginase characteristics. In view of this apparent dichotomy the present study was undertaken to characterize the arginase of a probable ammonotele, Pista pacifica. Characterization data reported for this worm include molecular weight, Michaelis constant, specificity, activation by sulfhydryl compounds and the presence of an active subunit. 
METHODS AND MATERIALS

\section{Enzyme Source and Assay}

Pista pacifica Berkeley was collected from the mudflats near Charleston, Oregon. Only freshly collected specimens were used in tissue preparations.

Preliminary tissue homogenates were prepared in either cetyltrimethylammoniumbromide for the localization of activity or in 50 mM Trischloride buffer, $\mathrm{pH} \mathrm{7.5,} \mathrm{containing} 100 \mathrm{mM} \mathrm{KC1}$ and $50 \mathrm{mM} \mathrm{MnCl}_{2}$ for the enzyme purification.

Unless otherwise stated the principle assay medium used at $25^{\circ} \mathrm{C}$ contained $0.85 \mathrm{M}$ arginine, $\mathrm{pH} 9.5 ; 5 \mathrm{mM} \mathrm{MnC1} 2 ; 0.5 \mathrm{M}$ sodium glycinate buffer, $\mathrm{pH}$ 9.5; and a sample of the enzyme in a final volume of $1 \mathrm{ml}$. The assay was stopped after ten minutes with $5 \mathrm{ml}$ of $0.5 \mathrm{M} \mathrm{HClO}_{4}$, and urea determined according to Archibald (1945). The colorimetric determination of urea is based on the red color formed when urea is heated in an acid solution with isonitrosopropiophenone. One enzyme unit was defined as the amount of enzyme that produces one umole of urea per minute at $25^{\circ} \mathrm{C}$. Specific activity, was expressed in enzyme units per mg protein. Protein was determined by the method of Lowry et al., (1951) as modified by Linn \& Lehmann (1965). Bovine serum albumin was used as a standard. The possibility that the worm was producing urea was tested by using Nessler's Reagent as described by Hult (1969), by the method of Ternberg \& Hershey (1964), and by the method of Fawcett \& Scott (1960). The tests for possible urea production included samples of fluid from 
the tube itself and from animals placed in a small amount of sterile sea water for several days. In all cases urea was not detected. From these preliminary tests it appears that Pista pacifica is primarily an ammonotele.

Molecular Weight

An estimate of the molecular weight of Pista pacifica arginase was made on Sephadex G-200. The eluting solution was $100 \mathrm{mM} \mathrm{KCl}-50 \mathrm{mM}$ Tris-HC1 - $50 \mathrm{mM} \mathrm{MnCl}{ }_{2}, \mathrm{pH} 7.5$. With a $20 \mathrm{~cm}$ pressure head, the column $(2 \times 150 \mathrm{~cm})$ had a flow rate of $15 \mathrm{ml} / \mathrm{hr}$ at $10^{\circ} \mathrm{C}$. Blue dextran $(2,000,000$ molecular weight), bovine catalase $(232,000$ molecular weight $)$, bovine serum albumin $(68,000$ molecular weight), ovalbumin $(43,000$ molecular weight), $\alpha$ chymotrypsinogen A $(25,700$ molecular wel.ght) and sperm whale metmyoglobin $(17,200$ molecular weight) were used as standards. Fractions were assayed for arginase activity.

\section{Polyacrylamide Gel Electrophoresis}

Running and stacking gels were prepared as in Davis (1964) with the exception that both Tris buffer solutions were altered to $\mathrm{pH} 9.5$ and $\mathrm{pH}$ 7.5 respectively. Samples were dissolved in large pore solution and photochemically polymerized on top of the stacking gel. Electrophoresis was performed in Tris-glycine buffer at $\mathrm{pH}$ 9.2. Gels were stained with Amfdo Schwartz, and destained with $7 \%$ acetic acid according to Davis (1964).

\section{Sterile Sea Water}

To eliminate the possibility of bacterial contamination, fresh 
worms were placed in filtered, autoclaved sea water containing streptomycin sulfate $(1 \mathrm{mg} / \mathrm{ml})$ and penicillin $(0.3 \mathrm{mg} / \mathrm{ml})$. Each worm was maintained in a liter of water which was replaced twice a day with fresh, sterile sea water.

\section{Reagents}

L-arginine (free base), L-ornithine, streptomycin sulfate, penicillin-G, bovine serum albumin, dchymotrypsinogen A, bovine catalase, sperm whale metmyoglobin, dithiothreitol, $\gamma$-guanidinobutyric acid, $p-$ hydroxymercuribenzoate, L-canavanine, D-arginine, agmatine sulfate, $\beta-$ guanidinopropionic acid, 2-mercaptoethanol, argininic acid, L-cysteine, Sephadex G-200-120, and DEAE-cellulose were purchased from Sigma Chem. Co.; phenol reagent from Fisher; and blue dextran from Pharmacia. 
RESULTS

\section{Purification of Pista pacifica Arginase}

The scheme outlined below represents steps described in the purification of rat liver arginase (Schimke, 1962) and rabbit liver arginase (Vielle-Breitburd \& Orth, 1972) adapted for the purification of Pista pacifica arginase. The purification procedure is summarized in Table I and 1llustrated in Figures 1 and 2. Unless otherwise stated all procedures were carried out in the cold.

Extraction. Several worms were cut open in cold sea water and the intestine quickly removed, weighed and homogenized in a ground glass homogenizer with 3 volumes of $50 \mathrm{mM}$ Tris-HCl buffer containing $100 \mathrm{mM} \mathrm{KCl}$ and $50 \mathrm{mM} \mathrm{MnCl}{ }_{2}, \mathrm{pH} \mathrm{7.5}$. The homogenate was centrifuged for $15 \mathrm{~min}$ at $13,000 \times \mathrm{g}$ in a Sorvall $\mathrm{RC2}-\mathrm{B}$ refrigerated centrifuge and the pellet was discarded.

Heat Treatment. The supernatant fluid containing the enzyme activity was incubated at $60^{\circ} \mathrm{C}$ for $20 \mathrm{~min}$, cooled and centrifuged for $10 \mathrm{~min}$ at $13,000 \times \mathrm{g}$. The pellet was discarded.

Ethanol Fractionation. Three volumes of absolute ethanol containing $50 \mathrm{mM} \mathrm{MnCl}_{2}$ at $-10^{\circ} \mathrm{C}$ were added to the supernatant. The resulting precipitate was removed by centrifugation for $10 \mathrm{~min}$ at $15,000 \times \mathrm{g}$ at $-10^{\circ} \mathrm{C}$. The pellet was then resuspended in a small amount of $0.01 \mathrm{M}$ TrisHCl buffer, pH 9.0 and dialyzed over night against the same buffer.

DEAE-cellulose Chromatography. The dialyzed solution was placed on a DEAE-cellulose column $(2 \times 10 \mathrm{~cm})$ equilibrated with $0.01 \mathrm{M}$ Tris-HC1, 
$\mathrm{pH} 9.0$. The column was then washed with two void volumes of the equilibration buffer. Enzyme elution was performed with a linear gradient of $\mathrm{NaC1}$ from 0 to $0.4 \mathrm{M}$ in the same buffer. The activity was eluted at a narrow range of molarity (approximately $0.2 \mathrm{M}$ ) in a single broad peak. No additional arginase activity was eluted by washing the column with the same buffer containing $1 \mathrm{M} \mathrm{NaCl}$. The active fractions were pooled and lyophilized (Figure 1).

Chromatography on Sephadex G-200. Lyophilized enzyme was redissolved in $2 \mathrm{ml}$ of $0.01 \mathrm{M}$ Tris-HC1, $\mathrm{pH} \mathrm{9.0,} \mathrm{and} \mathrm{chromatographed} \mathrm{on} \mathrm{Sepha-}$ dex G-200. The column $(2 \times 130 \mathrm{~cm})$ was previously equilibrated with the same buffer. The enzyme eluted as a single symmetrical peak. The active fractions were pooled and represented the primary enzyme source (Figure 2). In the following text it will be referred to as G-200 enzyme.

TABLE I

PURIFICATION OF Pista pacifica ARGINASE

\begin{tabular}{lccccc}
\hline Procedure & $\begin{array}{l}\text { Vo1 } \\
\text { m1 }\end{array}$ & $\begin{array}{c}\text { Total } \\
\text { activity } \\
\text { unfts }\end{array}$ & $\begin{array}{c}\text { Total } \\
\text { protein } \\
\text { mg }\end{array}$ & $\begin{array}{c}\text { Yield } \\
\%\end{array}$ & $\begin{array}{c}\text { Specific } \\
\text { activity } \\
\text { units/mg }\end{array}$ \\
\hline Extract & 10 & 25 & 310.2 & 100 & 0.082 \\
$\begin{array}{l}\text { Extract } \\
\text { supernatant }\end{array}$ & 9 & 23.6 & 21.87 & 94 & 1.07 \\
Heat & 8.5 & 17.34 & 7.73 & 69 & 2.24 \\
ETOH & 2 & 16.5 & 1.56 & 66 & 10.57 \\
DEAE* & 5 & 16 & 0.47 & 64 & 34.64 \\
G-200 & 20 & 15.9 & 0.168 & 63 & 94.8 \\
\hline
\end{tabular}

* After lyophilization and redissolution. 


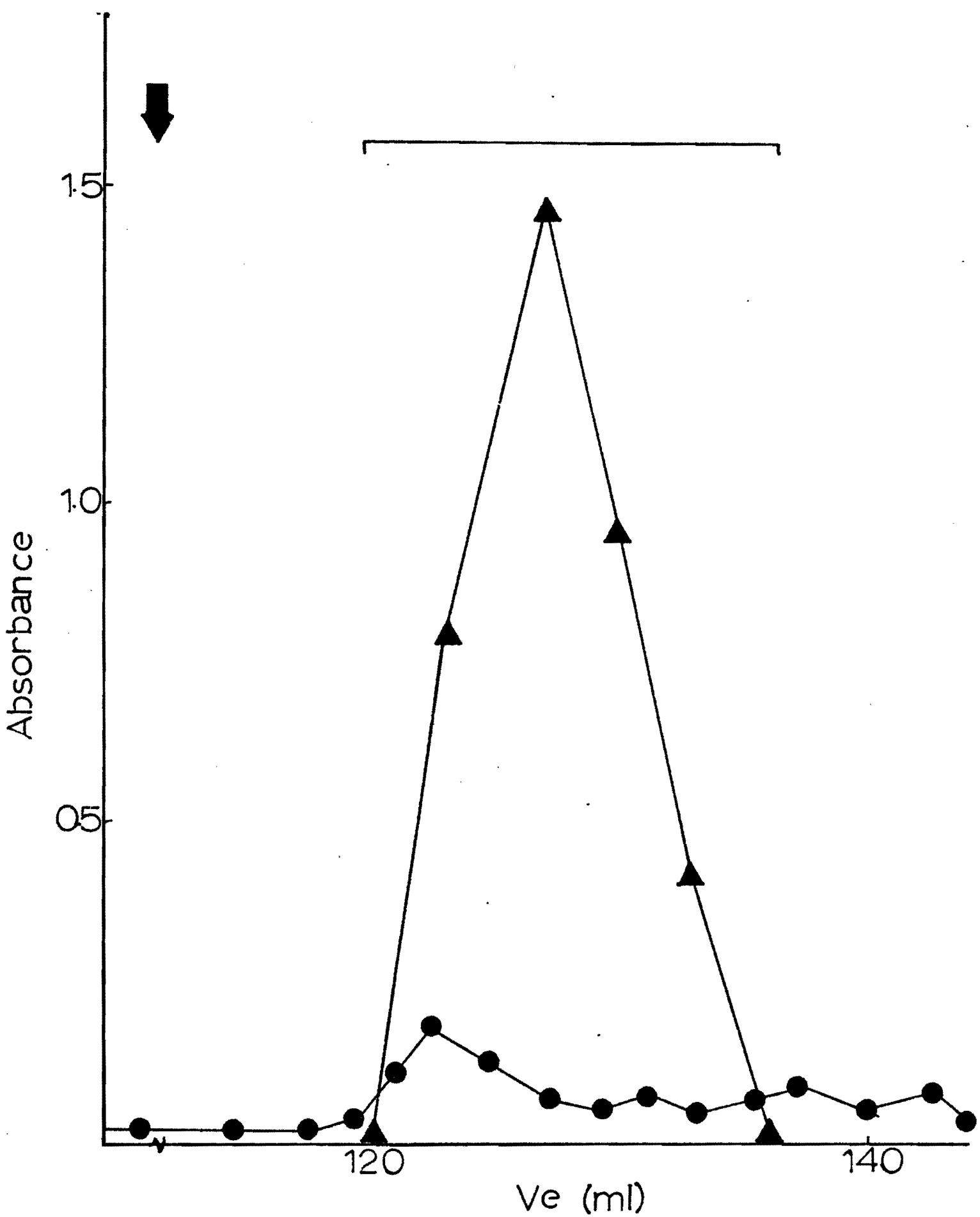

Figure 1. DEAE-cellulose chromatographic fractionation of $\mathrm{P}$. pacifica arginase after ethanol fractionation. The active fractions were pooled as indicated by the bar and lyophilized. The arrow indicates the start of the salt gradient. 's represent protein concentration measured at $280 \mathrm{~nm}$; $\Delta^{\prime}$ 's represent arginase activity determined colorimetrically by absorbance at $540 \mathrm{~nm}$. 


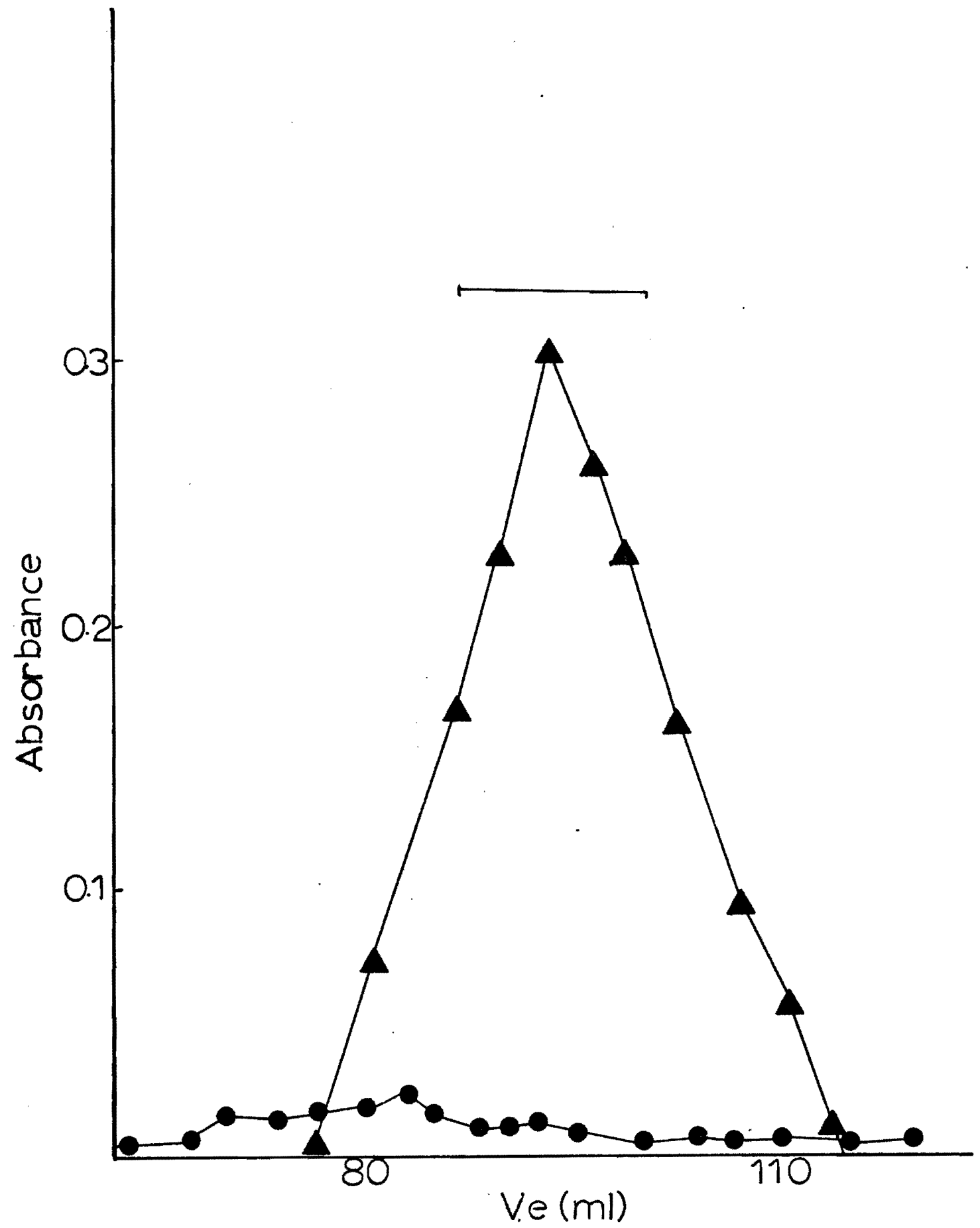

Figure 2. Sephadex $\mathrm{G}-200$ gel filtration of polychaete arginase after DEAE-cellulose chromatography. The active fractions were pooled as indicated by the bar. 's represent protein concentration measured at $280 \mathrm{~nm}$. A's represent arginase activity determined colorimetrically by absorbance at $540 \mathrm{~nm}$. 
The specific activity of the enzyme after chromatography on Sephadex G-200 was about 1000-fold greater than the specific activity of the crude extract. If the G-200 enzyme is lyophilized and electrophoresed on polyacrylamide gels at $\mathrm{pH} 9.2,8$ bands of varying intensities will appear in the gels. Whether these bands represent impurities or breakdown products of the enzyme itself has not yet been determined.

\section{Distribution of Arginase}

Arginase was present in the tentacles, body wall and gut tissues of P. pacifica (Table II). Whether the activity in the tentacles and the intestine could be attributed to bacterial origèn cannot be said though worms maintained in sterile sea water for 72 hours still exhibited arginase activity ( $\mathrm{Table}$ III). The intestine was consistently the richest source of arginase, particularly in terms of total units.

TABLE II

DISTRIBUTION OF ARGINASE IN THE TISSUES OF Pista pacifica

\begin{tabular}{rrrrrrr}
\hline worm & tentacles & esophagus & $\begin{array}{c}\text { anterior } \\
\text { stomach }\end{array}$ & $\begin{array}{l}\text { posterior } \\
\text { stomach }\end{array}$ & intestine & body wal1 \\
\hline 1 & $216 *$ & 79.6 & 0.22 & 0.25 & 67.9 & 0.91 \\
2 & 22.7 & 0.5 & 0.16 & 0.24 & 17.7 & 0.57 \\
3 & 120.0 & 5.5 & 0.90 & 0.40 & 12.6 & 0.68 \\
4 & 1.1 & 11.4 & 0.36 & 0.10 & 18.6 & 0.58 \\
5 & 1.5 & 1.7 & 0.70 & 0.24 & 95.8 & 0.90 \\
6 & 66.0 & 1.8 & 0.50 & 0.28 & 82.0 & 0.90 \\
\hline
\end{tabular}

* umoles urea/min/mg protein $\times 1000$

Worms were dissected and the tissues removed, weighed and homogen1zed in 9 vol of CTAB. $0.2 \mathrm{mls}$ homogenate were added to the assay medium. 
TABLE III

DISTRIBUTION OF ARGINASE IN THE TISSUES OF

Pista pacifica MAINTAINED IN STERILE

SEA WATER FOR 72 HOURS

\begin{tabular}{ccccccc}
\hline worm tentacles esophagus & $\begin{array}{c}\text { anterior } \\
\text { stomach }\end{array}$ & $\begin{array}{l}\text { posterior } \\
\text { stomach }\end{array}$ & intestine body wall \\
\hline $1 *$ & $83.0 * *$ & 0 & 0.27 & 3.58 & 38.6 & 1.47 \\
2 & 59 & 0.43 & 0.10 & 1.32 & 13.5 & 0.97 \\
3 & 6.3 & 0 & 0.20 & 1.82 & 34.2 & 0.97 \\
4 & 12.6 & 0.33 & 0.27 & 1.84 & 20.2 & 1.16 \\
5 & 1.7 & 0 & 0.2 & 0.69 & 22.8 & 0.97 \\
\hline
\end{tabular}

* control

** umoles urea/min/mg protein $\times 1000$

Worms were dissected and the tissues removed, weighed and homogenized in 9 vol of CTAB. $0.2 \mathrm{ml}$ of homogenate were added to the principle assay medium.

pH Optimum

A pH optimum of 10.5 was observed in four different experiments. The results of one experiment are shown in Figure 3. Although the optimal $\mathrm{pH}$ was 10.5 assays were conducted at $\mathrm{pH} 9.5$ in this study so that results could be compared with reported data (Hirsch-Kolb et al., 1970).

\section{Effect of Temperature}

The effect of temperature on $\underline{P}$. pacifica arginase is shown in Figure 4. Figure 5 shows a plot of $\log \mathrm{V}$ versus $1 / \mathrm{T}$ for temperatures between $273-333^{\circ} \mathrm{K}$. From this graph the energy of activation (E) was calculated according to: slope $=-E / 4.576$. Energy of activation was found to be $8.09 \mathrm{kcal} / \mathrm{mole}$. 


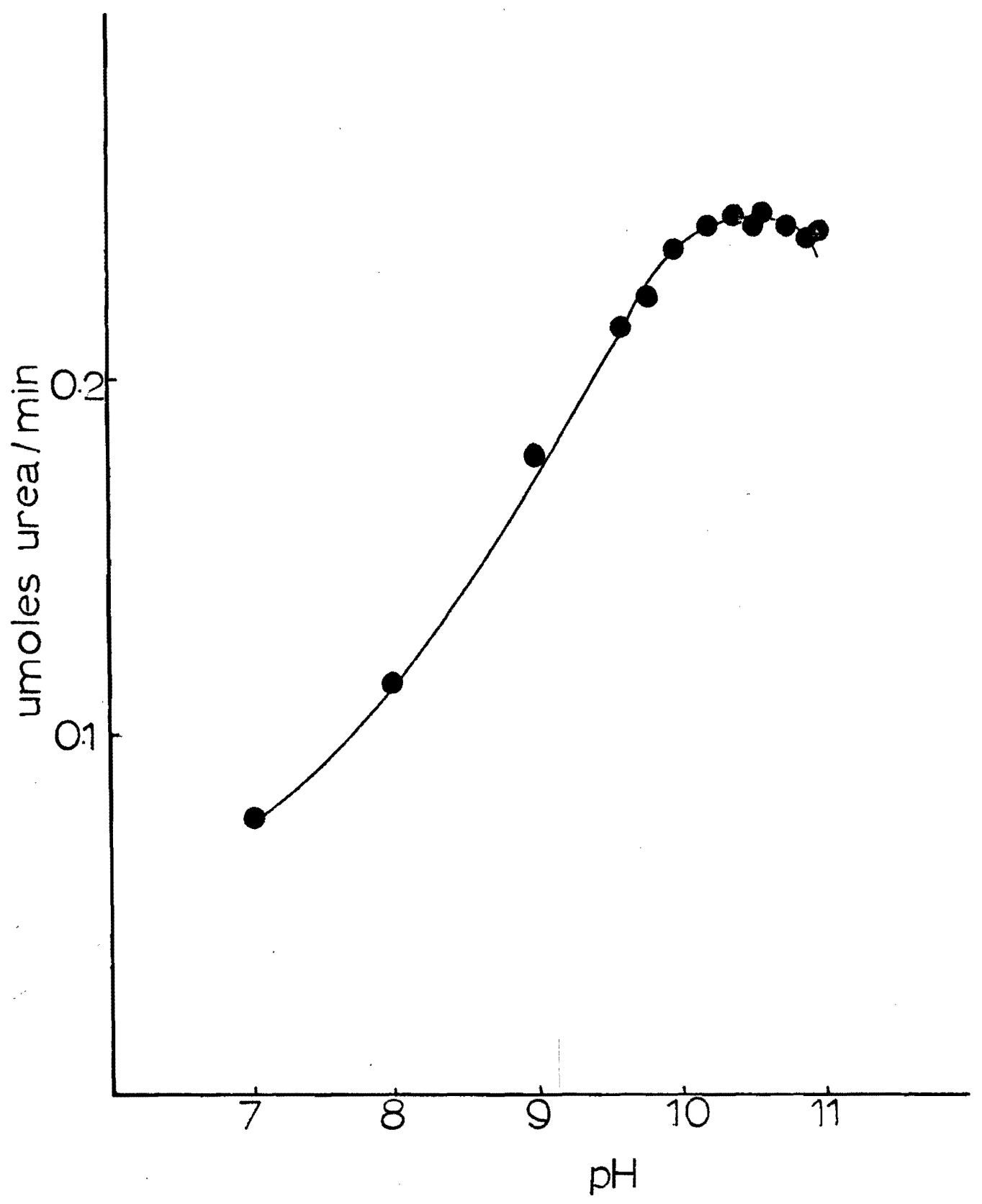

Figure 3. $\mathrm{pH}$ optimum of Pista pacifica arginase. $50 \mathrm{mM}$ sodium glycinate was used as a buffer between $\mathrm{pH} 9$ and $11 ; 50 \mathrm{mil}$ Tris-HCl was used below $\mathrm{pH} 9$. Two-tenths $\mathrm{ml}$ enzyme $(1 \mathrm{mg} / \mathrm{ml})$ was used in the principle assay medium that was adjusted to the indicated $\mathrm{pH}^{\prime} \mathrm{s}$. 


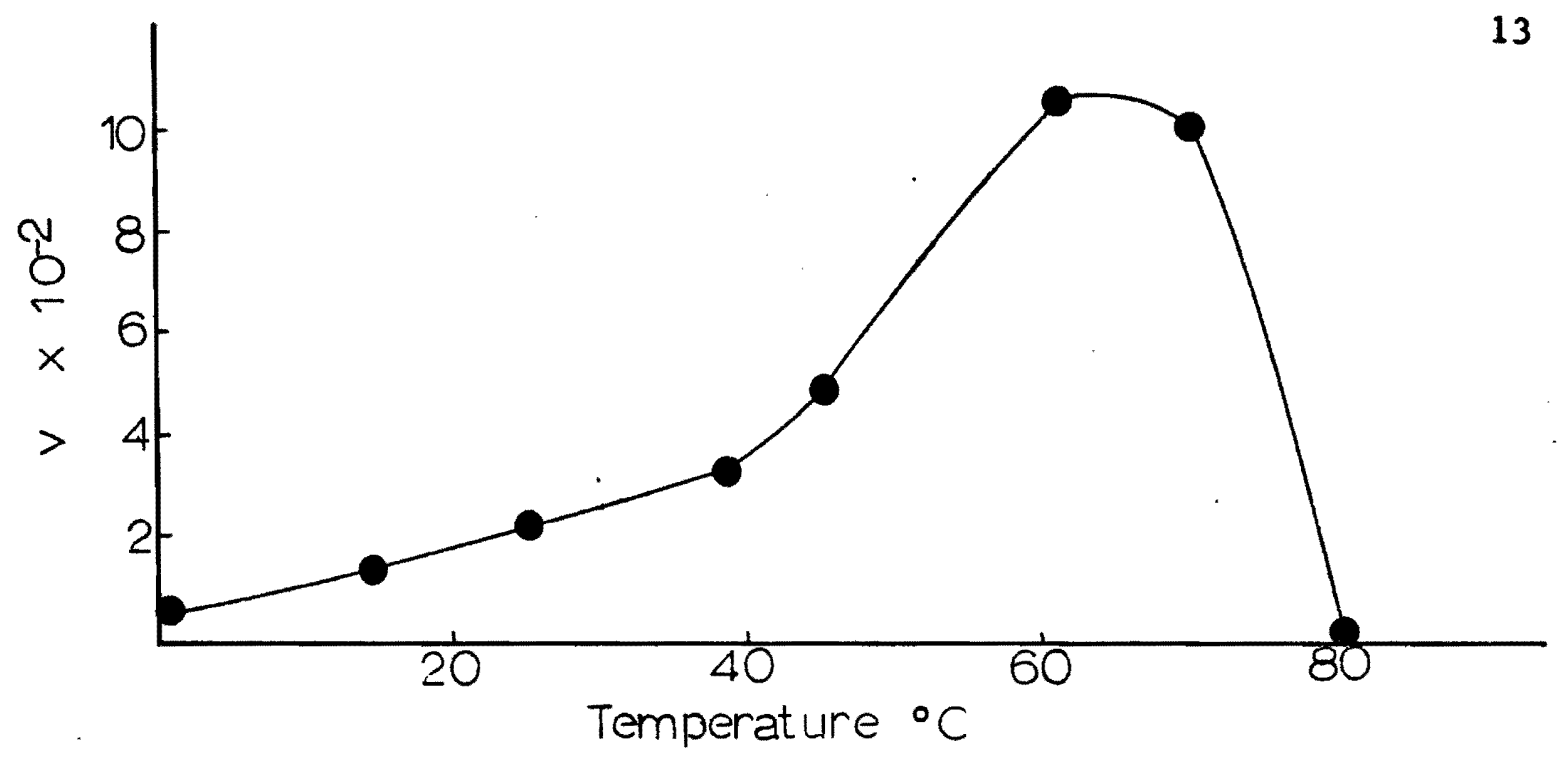

Figure 4. The effect of temperature on $\underline{P}$. pacifica arginase. A plot of temperature versus initial velocity. Two-tenths $\mathrm{ml}$ enzyme $(1 \mathrm{mg} / \mathrm{ml})$ was used in the assay medium equilibrated to the appropriate temperatures.

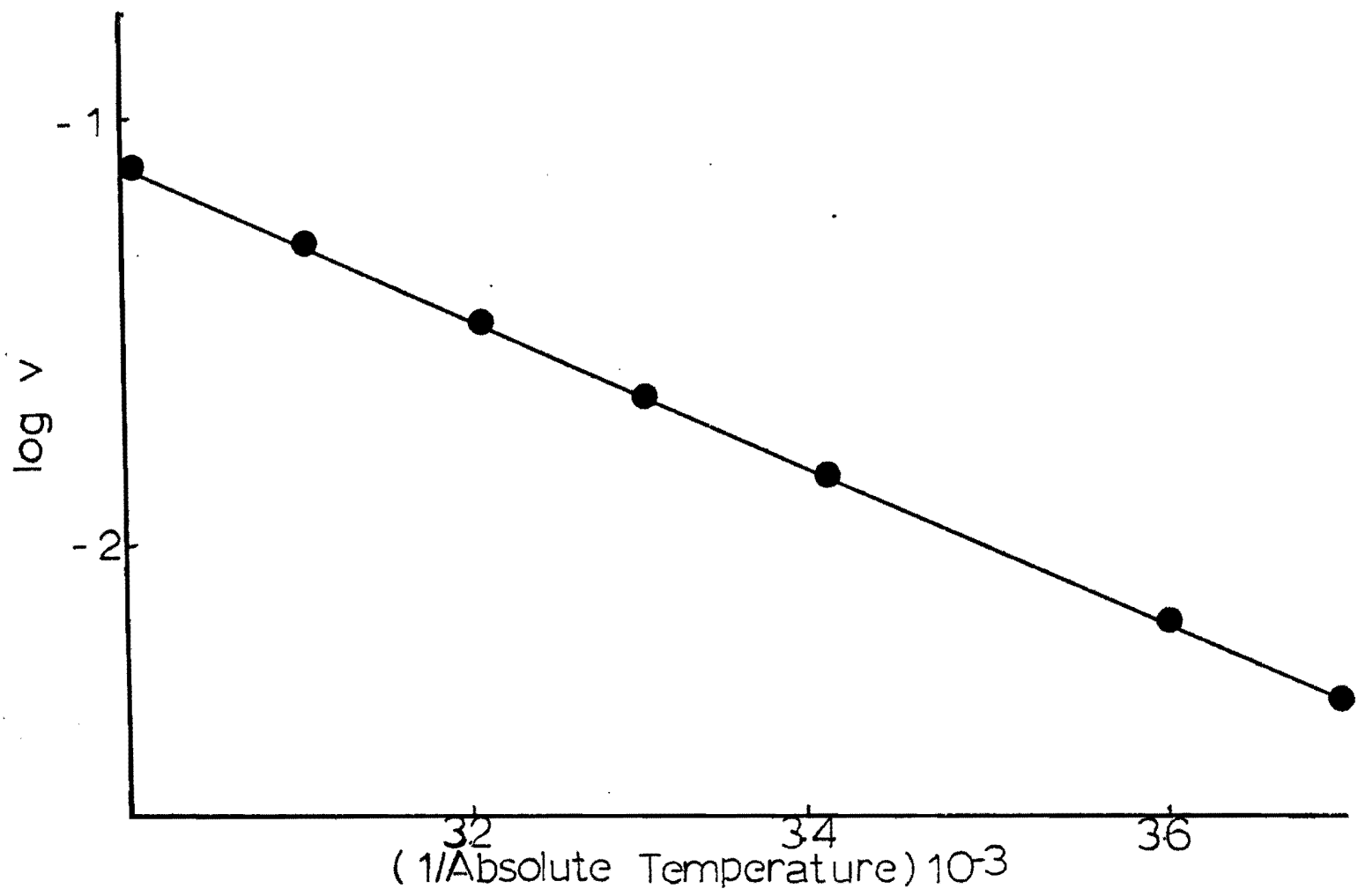

Figure 5. Plot of $\log \mathrm{V}$ versus $1 / \mathrm{T}$ from which the energy of activation was obtained. Two-tenths $\mathrm{m} 1 \mathrm{G}-200$ enzyme ( $1 \mathrm{mg} / \mathrm{m} 1$ ) was used in the assay medium equilibrated to the appropriate temperatures. 


\section{Substrate Kinetics}

The apparent Michaelis-Menten constant for L-arginine was 155 $160 \mathrm{mM}$ in several experiments. As shown in Figure 6 there was no indication of Inhibition by high substrate concentrations. The substrate concentration used for conducting assays on $\underline{P}$. pacifica arginase was $0.85 \mathrm{M}$. At this concentration $95-100 \%$ of the calculated maximum velocity (Vm) was obtained.

On the same graph L-ornithine $(100 \mathrm{mM})$ appears to be a competitive inhibitor. Hill plots for both enzyme and enzyme + inhibitor at the concentrations shown yield $n$ values of 1.034 and 1.040 respectively, where $n$ equals the slope of $\log (V m-V o /$ Vo versus $\log s$ (Figure 7).

\section{Effect of $\mathrm{Mn}^{2+}$ Concentration}

$\mathrm{Mn}^{2+}$ has been shown to be a metallic cofactor for a number of arginases although variable effects have been reported. Enzyme incubated for $30 \mathrm{~min}$ in the principle assay system seemed unaffected by various $\mathrm{Mn}^{2+}$ concentrations at $25^{\circ} \mathrm{C}$ and $\mathrm{pH} 9.5$ (Table IV).

\section{Specificity}

Agmatine sulfate, D-arginine, L-arginine, argininic acid, L-canavanine, $\gamma$-guanidinobutyric acid, and $\beta$-guanidinopropionic acid were tested as potential substrates. Only two were hydrolyzed to urea at an appreciable rate, L-arginine and L-canavanine (Table V). The ratio of arginase to canavanase was about 22 at $\mathrm{pH} 9.5$. 


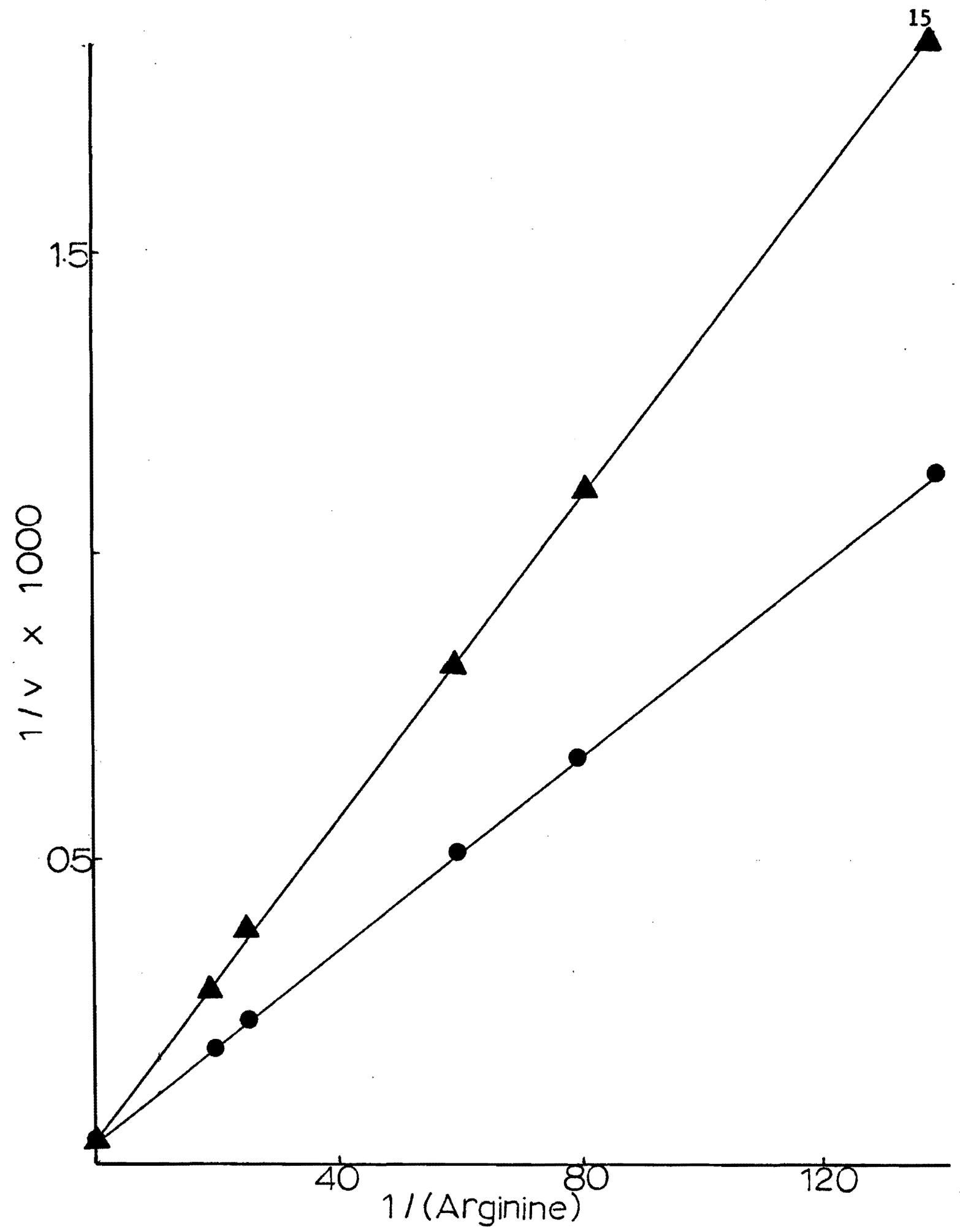

Figure 6. Kinetic behavior of $\underline{P}$. pacifica arginase. A double reciprocal plot of $1 / v$ versus $1 / \mathrm{s}$ for both enzyme and enzyme + inhibitor. The reaction mixture contained the concentration of arginine indicated $+0.1 \mathrm{~m} 1$ of G-200 enzyme. 9 's represent the enzyme kinetics without ornithine; $\Delta$ 's represent enzyme activity in the presence of $0.1 \mathrm{ml} 100 \mathrm{mM}$ ornithine. 


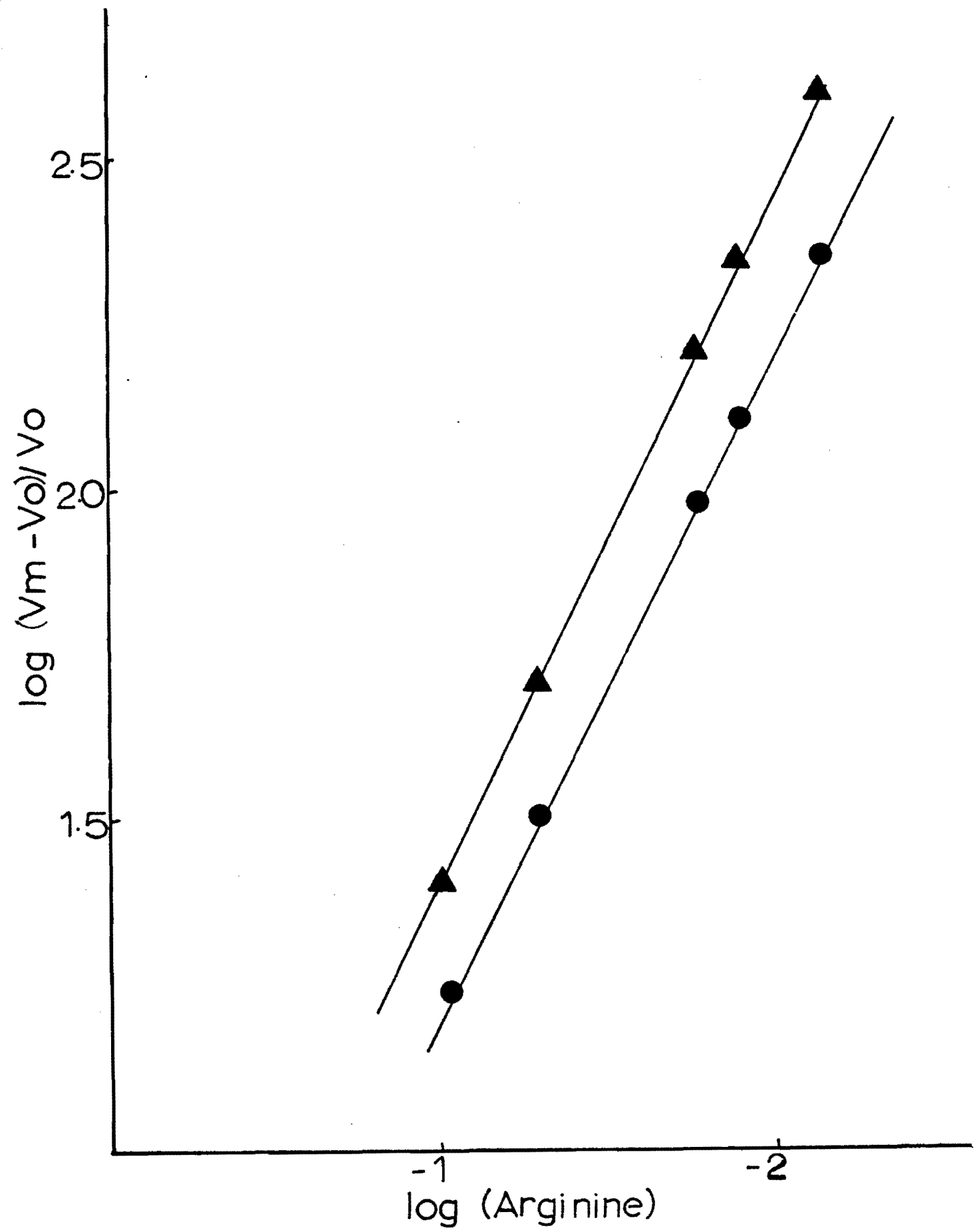

Figure 7. Hi11 plot of Pista pacifica arginase kinetics. 's represent the reaction mixture + enzyme; $\Delta$ 's represent the reaction mixture + enzyme + inhibitor. 
TABLE IV

THE EFFECT OF $\mathrm{Mn}^{2+}$ CONCENTRATION ON Pista pacifica ARGINASE ACTIVITY

$\mathrm{Mn}^{2+} \mathrm{mM} \quad$ umole urea formed $/ 30 \mathrm{~min}$

0

0.312

0.025

0.315

0.05

0.310

0.10

0.315

0.50

0.309

1.0

0.310

2.5

0.312

5.0

0.310

One-tenth $\mathrm{ml}$ of enzyme ( $1 \mathrm{mg} / \mathrm{ml})$ from the final purification step (G-200) was incubated for $30 \mathrm{~min}$ in the principle assay system except that the $\mathrm{Mn}^{2+}$ concentration was varied as indicated.

\section{Effect of Sulfhydry I Compounds}

Cysteine, dithiothreitol, reduced glutathione, 2-mercaptoethanol were added to the assay medium and their effect noted in Table VI. A11 compounds and reagents tested had a stimulatory effect on polychaete arginase.

The addition of one umole of p-hydroxymercuribenzoate (PMB), a sulfhydryl inhibitor, had no effect when the enzyme and PMB were incubated for 60 min in the principle assay medium. When PMB was increased to $5 \mathrm{mM}$ a slight stimulatory effect was noticed. 
TABLE V

SUBSTRATE SPECIFICITY OF Pista pacifica ARGINASE

Compound

umoles urea released $/ \mathrm{hr}$ $\mathrm{pH} 7.5$ $\mathrm{pH} 9.5$

Agamatine sulfate

0

0

D-arginine

0

0

L-arginine

0.072

0.620

Argininic acid

0

0

L-canavanine

0.014

0.028

$\nu$-guanidinobutyric acid

0

0

B-guanidinopropionic acid

0

0

One-tenth $\mathrm{m} 1$ of $\mathrm{G}-200$ enzyme ( $1 \mathrm{mg} / \mathrm{m} 1)$ was incubated for $60 \mathrm{~min}$ with each of the listed substrates in the principle assay system. Each of the substrates were adjusted to the indicated $\mathrm{pH}$. Sodium glycinate was used as a buffer at $\mathrm{pH} 9.5$ and $50 \mathrm{mM}$ Tris-HCl was used at $\mathrm{pH} \mathrm{7.5.}$

\section{Molecular Weight}

The molecular weight of Pista pacifica arginase, determined from the chromatography of the enzyme through Sephadex G-200, was estimated as 200,000 (Figure 8).

\section{Appearance of an Active Subunit}

Following heat treatment, acetone fractionation was tried as a possible purification method. One and a half sample volumes of acetone at $-10^{\circ} \mathrm{C}$ were slowly added to the heat supernatant. The mixture was centrifuged at $13,000 \times \mathrm{g}$ for 5 minutes at $-10^{\circ} \mathrm{C}$, and the pellet resuspended in one volume $50 \mathrm{mM}$ Tris- $\mathrm{HCl}$ containing $100 \mathrm{mM} \mathrm{KCl}$ and $50 \mathrm{mM} \mathrm{MnCl}_{2}, \mathrm{pH} 7.5$. 
TABLE VI

THE EFFECT OF SULFHYDRY COMPOUNDS ON Pista pacifica ARGINASE

Compound

umoles urea produced/hr

None

0.685

Cysteine

1.180

Dithiothreitol

1.365

Reduced glutathione

1.190

2-mercaptoe thanol

2.500

Five umoles of each sulfhydryl compound were added to the reaction medium. The reaction was started with $0.1 \mathrm{ml} \mathrm{G}-200$ enzyme $(1 \mathrm{mg} / \mathrm{ml})$ and incubated for $60 \mathrm{~min}$. Standards were prepared in the presence of the same amount of sulfhydryl compound used for colorimetric correction.

The solution was then dialyzed for 2 hours against the same buffer. The sample was then chromatographed on a Sephadex G-200 column $(2 \times 150 \mathrm{~cm})$ equilibrated in the same buffer. The enzyme eluted in two peaks, one of approximately 200,000 molecular weight and an apparent dissociation product with a molecular welght about 42,000 (Figure 9).

An active subunit could also be produced when the active fractions of the G-200 enzyme in the purification scheme of polychaete arginase were pooled and lyophilized. The lyophilized material was redissolved in Tris-HC1 buffer, $\mathrm{pH} 7.5$, placed on a G-200 column and eluted as before. Fractions included two activity peaks, one corresponding to the large molecular weight unit and the other to 34,000 . The peak fraction of the lower molecular weight was rechromatographed on the column and eluted at $15 \mathrm{ml} / \mathrm{hr}$. There was no evidence of aggregation. Arginase activity ap- 


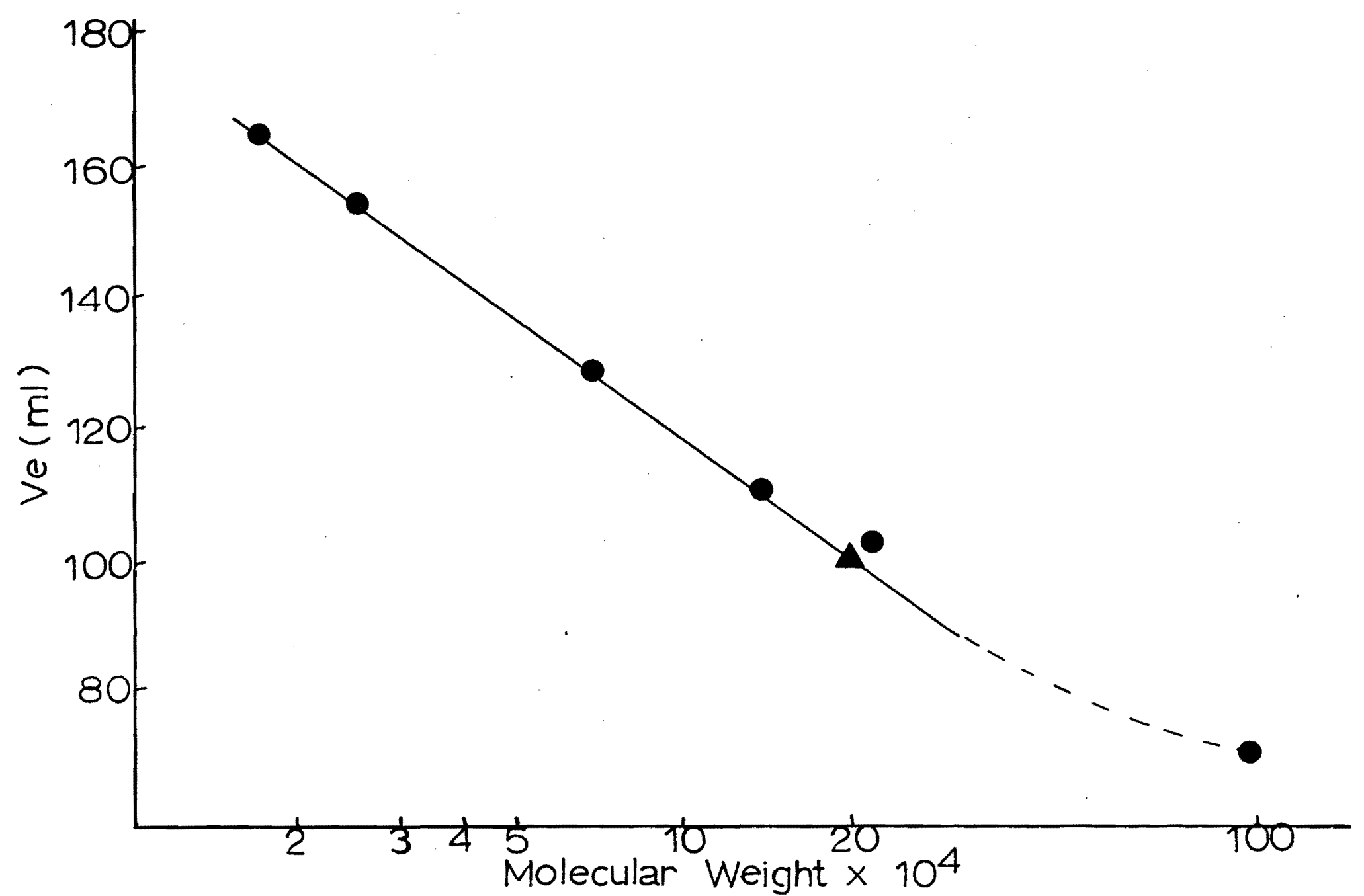

Figure 8. Estimate of molecular weight of Pista pacifica arginase. 's from left to right: sperm whale metmyoglobin, chymotrypsinogen A, bovine serum albumin, lactate dehydrogenase, catalase, and blue dextran. A: Pista pacifica arginase. 


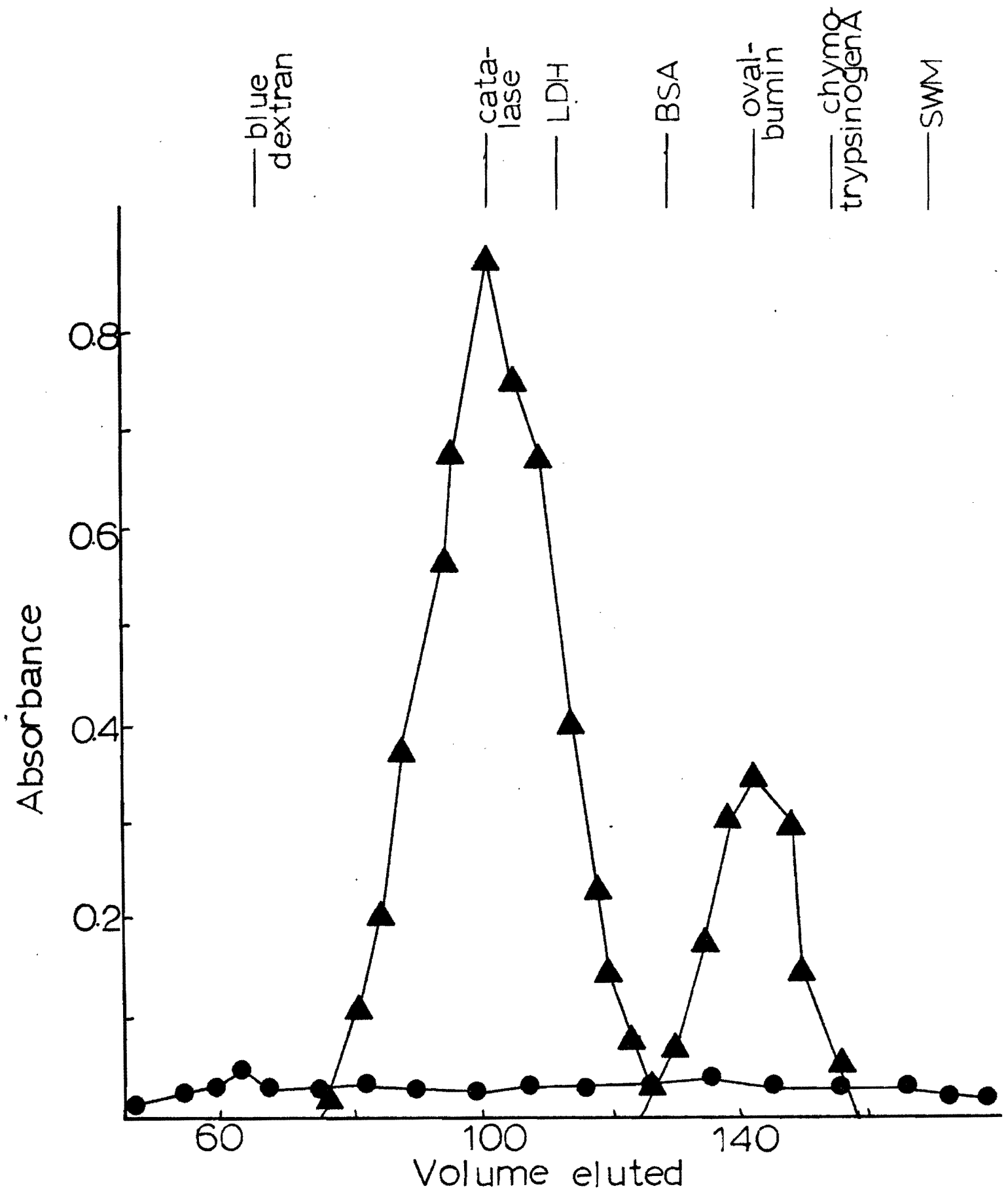

Figure 9. Breakdown of $\underline{P}$. pacifica arginase after acetone fractionation. 's represent protein concentration measured at 280 nm. A's represent arginase activity determined colorimetrically by absorbance at $540 \mathrm{~nm}$. Calibrants were: blue dextran, bovine catalase, bovine serum albumin, lactate dehydrogenase, ovalbumin, achymotrypsinogen $A$, and sperm whale metmyoglobin. 
peared in the same fractions as before: molecular weight of 34,000 (Figure 10). Active fractions were pooled and lyophilized.

\section{Polyacrylamide Gel Electrophoresis of Subunit}

Lyophilized subunit ( $2 \mathrm{mg} / \mathrm{m} 1)$ from the dissociation of the G-200 enzyme, migrated as a single dark band during polyacrylamide gel electrophoresis at $\mathrm{pH}$ 9.2. Another, lighter band was observed on several occasions. Whether this band represents an impurity, closely allied subunit structure, or an artifact of electrophoresis has not yet been determined.

Michaelis Constant of Subunit

Values of 114 - $118 \mathrm{mM}$ were obtained for the $\mathrm{Km}$ of the subunit arginase on a double reciprocal plot of $1 /$ Vo versus 1 /substrate concentrations. A Hill plot indicated an $n$ value of 1.07 where $n$ equals the slope of $\log (V m-V \partial /$ Vo versus $\log S$ (Figure 11 ).

Effect of $\mathrm{Mn}^{2+}$ Concentrations on the Subunit

The subunit, incubated for $30 \mathrm{~min}$ in the principle assay system, appeared to be unaffected by $\mathrm{Mn}^{2+}$ concentrations (Table VII). 

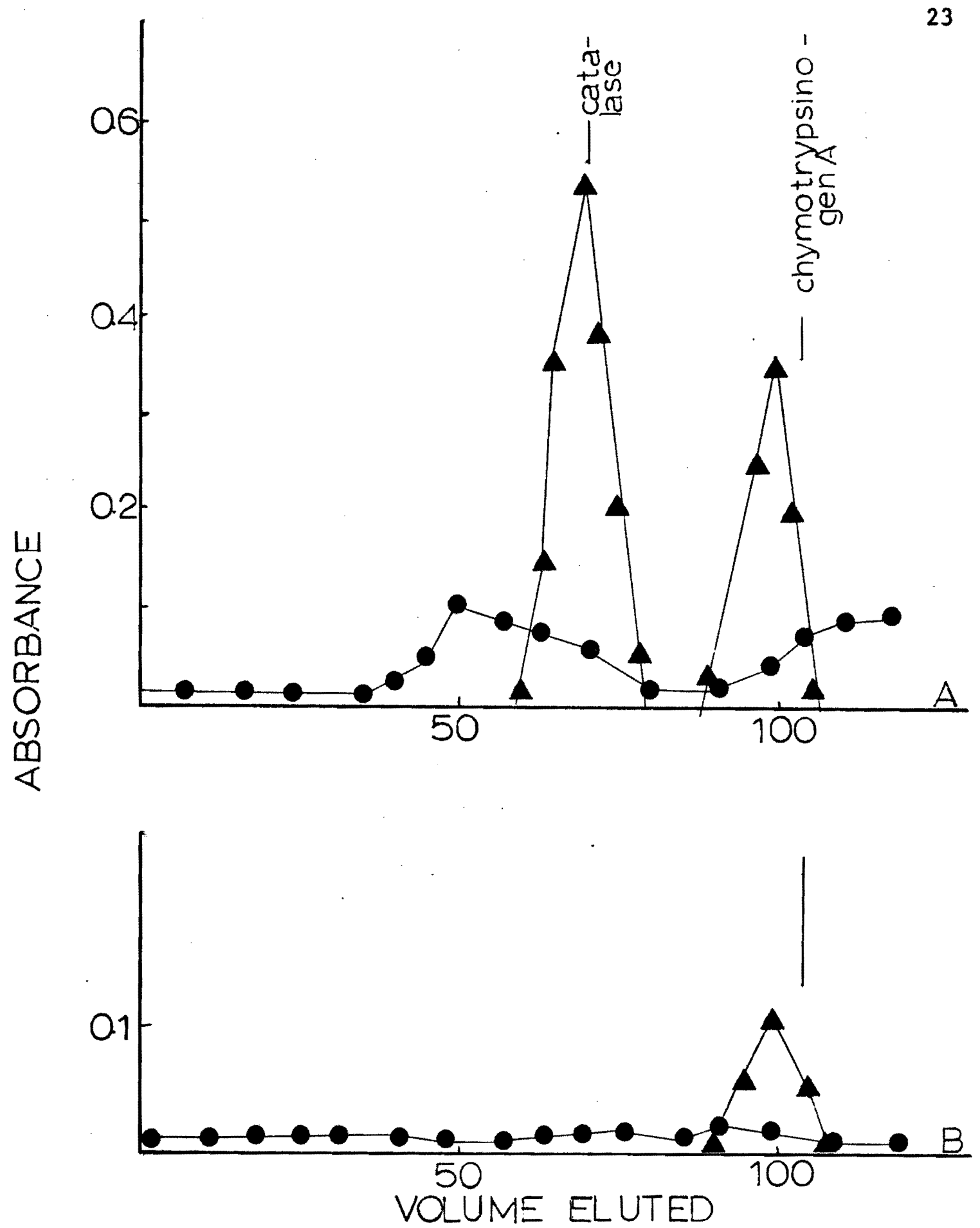

Figure 10. Appearance of subunit on Sephadex G-200. A, breakdown of enzyme after redissolution in buffer following lyophilization. $B$, rechromatography of subunit from A showing the absence of aggregation. 's represent protein concentration measured at 280 nm. $\Delta$ 's represent arginase activity measured as urea production determined colorimetrically at $540 \mathrm{~nm}$. 


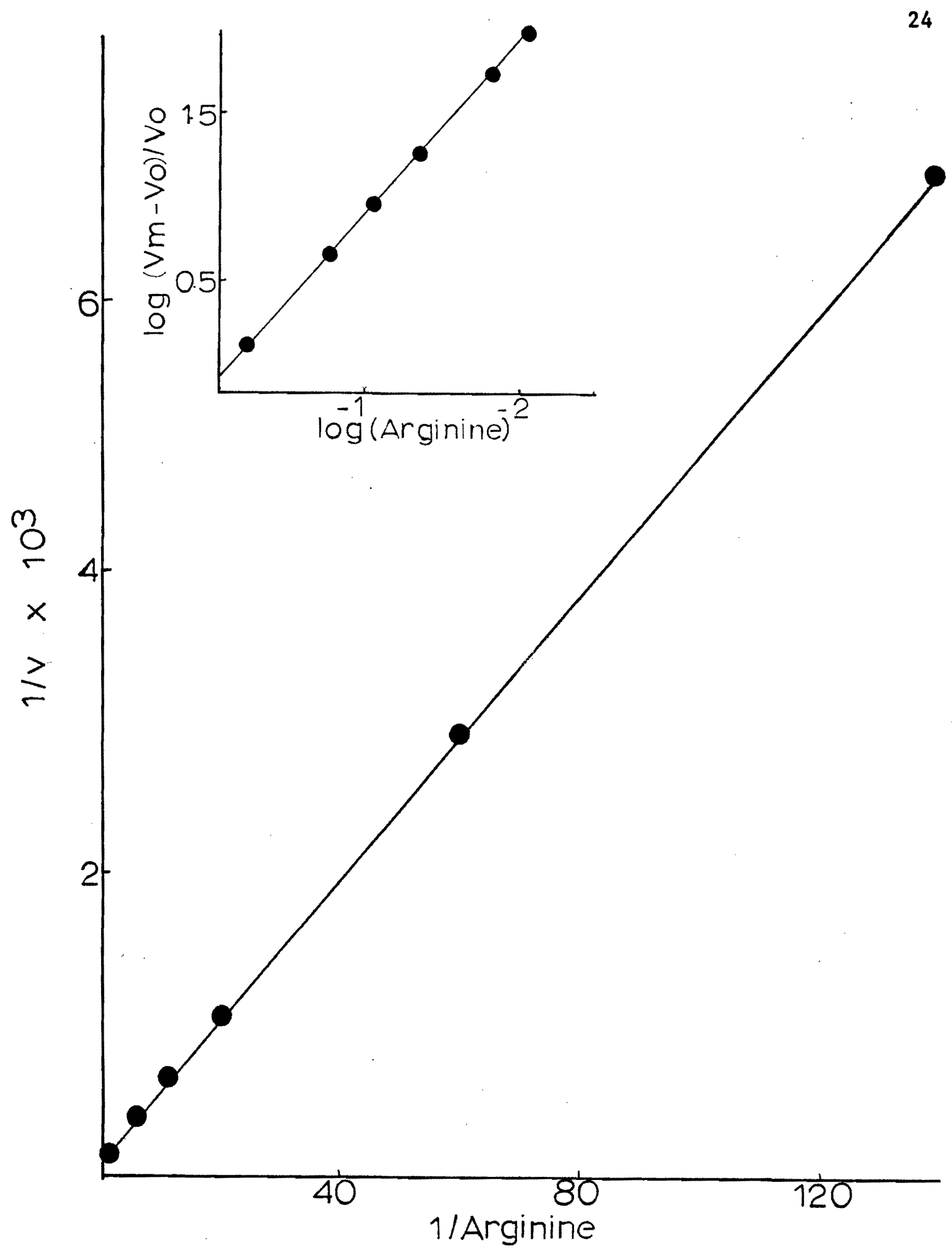

Figure 11. Lineweaver-Burke plot of affinity of subunit for substrate. Inset: Hill plot of indicated data. Enzyme source was 1solated subunit $(1 \mathrm{mg} / \mathrm{ml})$ added to the assay medium. 
TABLE VII

EFFECT OF $\mathrm{Mn}^{2+}$ CONCENTRATION ON Pista pacifica SUBUNIT ACTIVITY

\begin{tabular}{lc}
\hline Mn $^{2+} \mathrm{mM}$ & umole urea formed/30 min \\
\hline 0 & 0.368 \\
0.025 & 0.368 \\
0.050 & 0.396 \\
0.100 & 0.370 \\
0.500 & 0.365 \\
1.000 & 0.387 \\
2.500 & 0.376 \\
5.000 & 0.370 \\
\hline $\begin{array}{l}\text { One-tenth m1 of subunit from dissociated G-200 enzyme was incubated } \\
\text { In the principle assay medium with the above concentrations of manganous }\end{array}$
\end{tabular}


DISCUSSION

Despite the well established role of arginase in certain oligochaetes (Needham, 1957, 1960, 1962; Bishop \& Campbe11, 1965; Reddy \& Campbe11, 1968), few marine annelids have been investigated with regard to the presence of this enzyme, none with regard to its characteristics (Hult, 1969). Studies of arginase in oligochaetes have primarily focused on its presence, location, and role in connection with the other enzymes of the Krebs-Henseleit cycle. Needham (1960) reported that arginase activity in the gut of Lumbricus terrestris was maximal in the anterior part of the intestine declining to a minimum in the crop-gizzard region. In addition, he noted an inverse relationship between activity and the amount of chloragogen tissue. This tissue, possibly analogous to the vertebrate liver (Laverack, 1963), is characterized by a bright yellow color. In $\underline{P}$. pacifica the occurrence of the tissue containing the yellow pigment (chloragogen tissue) is restricted to the anterior stomach and to the intestine. The anterior stomach exhibits minimal arginase activity while the intestine has relatively high activity (Table II). A cursory histological examination indicated equal amounts of chloragogen tissue in both of these anatomical regions so that in Pista there does not seem to be a correlation, efther positively or Inversely, between the amount of chloragogen tissue and arginase activity.

The possibility that the arginase detected in Pista pacifica tissues is of bacterial origin cannot be ruled out. Arginase has been re- 
ported in Escherichia coli, Proteus vulgaris, Staph. aureus, and Bacil1is stabilis (Khramov \& Galaev, 1971). Unfortunately, no molecular weights or Michaelis constants are available for comparison. Fluctuations in bacterial arginase could explain the large variations observed in tissue activity (Tables II \& III) though such variations could also be due to the worm's arginase responding to feeding activities, metabo1ic functions, or tidal patterns. Worms could only be maintained three days in sterile sea water without their tubes which may have been insufficient to notice a significant difference in activity from fresh worms. The characteristics of arginase have undergone extensive evaluation in the past few years, in particular, their relationship to a specles' mode of nitrogen excretion. A comparison of $\underline{P}$. pacifica arginase to the enzymes of ureoteles and uricoteles summarized in Table vIII shows some similarities and some differences.

The molecular weights of arginase from uricotelic species have been found to be around 225,000-280,000 (Mora et al., 1965; Campbe11, 1966; Reddy \& Campbe11, 1969a). Based on the probable subunit structure of 30,000 , molecular weights in this range have been referred to as octamers (Reddy \& Campbe11, 1970). The value of 200,000 reported here for Pista pacifica arginase although it falls outside of this range probably represents an octamer. No heptameric arginases have been reported nor does it seem likely that they will be found as proteins containing an odd number of subunits are rare (Klotz, 1967). However, the estimation on gel filtration should be regarded as tentative until supplementary data such as ultracentrifugal studies on completely purified arginase are done. The difference in molecular weights of native Pista pacifica 
TABLE VIII

CHARACTERISTICS OF ARGINASE IN RELATION TO NITROTELISM*

\begin{tabular}{|c|c|c|c|c|c|c|c|}
\hline \multirow{2}{*}{$\begin{array}{l}\text { Nitrotelism } \\
\text { and } \\
\text { source }\end{array}$} & \multirow{2}{*}{$\begin{array}{l}\mathrm{Km} \\
\mathrm{mM}\end{array}$} & \multirow{2}{*}{$\begin{array}{l}\text { Molecular } \\
\text { weight } \\
\text { x } 1000\end{array}$} & \multirow{2}{*}{$\begin{array}{l}\text { Stability } \\
\text { during } \\
\text { dialysis }\end{array}$} & \multirow{2}{*}{$\begin{array}{l}\text { Arginase/ } \\
\text { canavanase }\end{array}$} & \multicolumn{2}{|c|}{ Inhibition } & \multirow{2}{*}{ Reference } \\
\hline & & & & & PCMB & Arginine & \\
\hline \multicolumn{8}{|l|}{ Ammonoteles } \\
\hline crayfish body wall & 2 & 225 & + & 3 & + & + & Hartenstein, 1972 \\
\hline Pista pacifica & 155 & 200 & + & 22 & - & - & Present study \\
\hline $\begin{array}{l}\text { axolot } \overline{l \text { liver }} \\
\text { earthworm }\end{array}$ & 16 & 27 & & & + & & $\begin{array}{l}\text { Mora et } \frac{\text { al. }}{\text { Reddy }} \text { \& } 1965 \\
1968\end{array}$ \\
\hline \multicolumn{8}{|l|}{ Ureoteles } \\
\hline rat liver & $10-40$ & 118 & + & 1.5 & - & \pm & $\begin{array}{l}\text { Mora et al. , 1966, } \\
1967 \text {; } \frac{\text { Hs ch-Kolb }}{\text { Greenberg. } 1968}\end{array}$ \\
\hline beef liver & 2.7 & . & ++ & 15 & + & & Brown, 1966 \\
\hline \multicolumn{8}{|l|}{ Uricoteles } \\
\hline chicken liver & 100 & 276 & - & 7 & + & - & Mora et al., 1966 \\
\hline gull liver & 2 & 134 & - & - & + & + & $\begin{array}{l}\text { Brown, 1966; Reddy } \\
\text { \& Campbe11, } 1970\end{array}$ \\
\hline lizard liver & $100-200$ & 276 & & & & & Mora et a1., 1965 \\
\hline Helix aspersa & 3.9 & 244 & & 10 & & - & $\begin{array}{l}\text { Campbe11, } 1966 ; \\
\text { Reddy \& Campbel1, } \\
1970 \text {; Baret et al. } \\
1972\end{array}$ \\
\hline silkmoth & 2.5 & 228 & & 24 & - & + & $\begin{array}{l}\text { Reddy \& Campbe11, } \\
\text { 1969a }\end{array}$ \\
\hline
\end{tabular}

* table adapted from Hartenstein (1972) 
arginase $(200,000)$ and that of Lumbricus terrestris $(30,000)$ is notable though unexplained at this time.

Molecular weights of 120,000 (tetramers) have been reported for ureoteles (Greenberg et al., 1956; Mora et al., 1966; Hirsch-Kolb et al., 1970). Hirsch-Kolb \& Greenberg (1968) have found the molecular weight of rat liver arginase to be 118,000 . The enzyme is composed of four subunits each of 30,800 molecular weight. When isolated the molecular weight of $\underline{P}$. pacifica subunit on gel filtration studies is approximately 34,000 , which is in close agreement with the rat liver subunit and the monomeric arginase of the earthworm (Reddy \& Campbel1, 1968).

The molecular welght of the subunit following acetone treatment was approximately 42,000 (Figure 9) although the two activity peaks were not completely separated as they were with the lyophilized subunit. This could represent an association-dissociation equilibrium generated by the harsh treatment. Harsh treatment may also account for the active monomer of rabbit liver arginase. When purified at low $\mathrm{pH}^{\prime} \mathrm{s}$ the native arginase of 118,000 molecular weight breaks down to a subuntt of 36,000 (Rogers \& Moore, 1963; Vielle-Breitburd \& Orth, 1972).

The high $\mathrm{Km}$ value obtained for polychaete arginase is in the range of the values ( $>100 \mathrm{mi}$ ) found for chicken liver and lizard liver, both uricoteles (Mora et al., 1965, 1966). As with chicken liver, high concentrations of arginine did not inhibit the enzyme. Competitive inhibition by L-ornithine is characteristic of chicken liver, Neurospora crassa (Mora et al., 1966), silkmoth arginases (Reddy \& Campbell, 1969a), and Pista pacifica arginase.

Sulfhydryl compounds have had a variable effect on reported argin- 
ases. Glutathione has had a stimulatory effect on arginase on several occasions (Campbell, 1966). Glutathione, dithiothreitol, 2-mercap toethanol, and cysteine have a stimulatory effect on both bullfrog arginase and bovine arginase (Carlisky \& Sadnik, 1972). The same effect was observed with Pista. On the other hand these compounds were slightly inhibitory in the case of insects (Reddy \& Campbell, 1969a). The activity toward L-arginine is inhibited by $\mathrm{p}$-chloromercuribenzoate in the crayfish (Hartenstein, 1971), chicken liver (Mora et al., 1966), cockroach fat body (Reddy \& Campbell, 1969a), and bullfrog kidney and bovine liver (Carlisky \& Sadnik, 1972). Rat liver (Mora et al., 1966) and silkmoth are unaffected (Reddy \& Campbe11, 1969a). Pista pacifica arginase is unaffected by p-hydroxymercuribenzoate, the sodium salt of the free acid form. (The "chloro" converts to "hydroxy" when the sodium salt is prepared). Effects of sulfhydryl reagents on arginase are quite variable. This may indicate differences in enzyme structure or it may reflect experimental conditions.

The arginases present in the livers of uricotelic and ureotelic animals have a similar substrate specificity. All hydrolyze L-arginine and to some extent L-canavanine (Mora et al., 1965). Helix pomatia and Helix aspersa also hydrolyze homoarginine (Baret et al., 1972). Arginase/canavanase ratios at $\mathrm{pH} 9-10$ for reported species have no apparent pattern. High ratios $(10)$ as that obtained for Pista arginase have been reported for rat liver (Mora et al., 1966), beef liver (Brown, 1966), and silkmoth (Reddy \& Campbe11, 1969a).

Few temperature optima have been reported. The arginase of the sockeye salmon has a temperature optimum of $45^{\circ} \mathrm{C}$ (Cvancara, 1971), 
Helix pomatia and Helix aspersa between $60-65^{\circ} \mathrm{C}$ (Baret et al., 1972), and horse liver arginase has a temperature optimum of $45-50^{\circ} \mathrm{C}$ (Greenberg \& Mohamed, 1945). The temperature optimum of Pista pacifica is approximate $1 \mathrm{y} 60^{\circ} \mathrm{C}$.

The majority of arginases appear to be activated by $\mathrm{Mn}^{2+}$. In these studies $\underline{P}$. pacifica does not exhibit this characteristic. This does not prove that $\mathrm{Mn}^{2+}$ is not required by the enzyme. The divalent cation may be tightly bound to the enzyme and thus be present in adequate amounts even in the absence of added $\mathrm{Mn}^{2+}$. The lack of activation of the native enzyme is also observed with the subunit. Hirsch-Kolb et al., (1970) reported that four molecules of manganese are bound to one molecule of fully activated rat arginase with different binding affinities. Two are loosely bound and two molecules of manganese are tightly bound. The removal of the two loosely bound lons results in a $50 \%$ loss of activity which can be reversed by an incubation at $55^{\circ} \mathrm{C}$ with $\mathrm{MnCl}_{2}$. When the two tightly bound ions are removed irreversible inactivation occurs. It may be that manganous lons are tightly bound to the arginase of $\underline{p}$. pacifica. This may explain the lack of activation. On the other hand, it may be that $\mathrm{Mn}^{2+}$ is not required for enzyme activity or perhaps another divalent metal ion would be more effective. Experiments should be carried out in EDTA (ethylenediaminetetraacetic acid) to determine whether $\mathrm{Mn}^{2+}$ was required or not.

In the search to categorize arginases with respect to modes of nitrogen excretion, reports on arginases of ureo-, ammono-, and uricoteles served more to point out the disparities rather than the similarities among arginase properties. Terms such as "ammonoureoteles" and "urico- 
teles with ureotelic ancestors" have been used to obscure differences and to maintain the theory of a distinction between arginases from ureotelic and uricotelic organisms. The information presented in this paper on an arginase from a terebellid worm, together with other recent data (Reddy \& Campbe11, 1970; Hartenstein, 1971) contradicts this theory and points out that none of the characteristics of arginase observed to date can be correlated with a particular mode of nitrotelism.

Perhaps a better way of distinguishing between arginases would be In terms of their function. A physiological function of the liver arginase is to form urea, a role which is clear from its participation in the multi-enzyme ornithine-urea cycle. Other roles for the enzyme, especially in nonhepatic tissues and in tissues where the other enzymes of the urea cycle have not been demonstrated, would include catalysis of the first step in the conversion of arginine to proline, a conversion known to occur in the udder of goats (Mepham \& Linze11, 1966), the mammary gland of rats (Yip \& Knox, 1972), and the fat body of insects (Reddy \& Campbe11, 1969b). Another functional arginase may serve to catalyze the breakdown of ingested arginine or arginine obtained from protein hydrolysis (Canedo et al., 1967; Soberón et al., 1967), as for example, via lysozymes (Tabor \& Tabor, 1969). Whether $\underline{P}$. pacifica arginase functions as an excretion arginase, a catabolic arginase, as a precursor arginase, or in a manner as yet unkown has not been empirically determined.

Although all of the ornithine cycle enzymes have not been assayed for in this animal, ornithine transcarbamylase has been detected in the Intestine according to the method of Brown \& Cohen (1959). Such activi- 
ty is suggestive of a functional omithine-urea cycle. However, several attempts to detect urea have been unsuccessful. A search for urease was also unsuccessful. If the arginase is not functioning to produce urea, perhaps it acts as a dietary arginase, or for the production of ornithine as a precursor of proline, or in conjunction with arginine phosphagens.

The appearance of an enzymatically active subunit is significant in comparison with the earthworm arginase and in possible terms of regulation. As previously stated, Lumbricus terrestris has a monomeric arginase of 27,000 molecular weight which is active in a functional urea cycle (Bishop \& Campbe11, 1965; Reddy \& Campbe11, 1968). Apparently a monomeric unit is sufficient for this catalysis but it raises the question of why the marine annelid developed an oligomeric arginase while retaining an active subunit, a subunit which is capable of catalyzing the reaction with a greater affinity for substrate than the intact protein. Unless, an arrangement of subunits is capable of regulating the appearance of product. Such regulation usually appears as an atypical plot (sigmoid curve) of substrate versus velocity and a Hill plot n value greater than 1 . The $\mathrm{n}$ value of 1.034 for $\underline{P}$. pacifica arginase would not indicate such regulation under the stated assay conditions. Possibly the enzyme has been "desensitized" (Monod et al., 1963) during purification procedures. Several research teams (Hochachka \& Mostafa, 1973; Gerhart \& Pardee, 1962) have noticed that the kinetics of the reaction catalyzed by a desensitized enzyme obey the Michaelis-Menten relation (hyperbolic curve) while in the presence of native enzyme the rate-concentration curve is sigmoid. Another possibility is that the 
regulation requires certain small molecules for activation. Cabello (1967) has indicated that arginase modified by sodium dodecyl sulfate exhibits a sigmoidal curve as a function of arginine concentration. He also suggested that natural analogues of dodecyl sulfate, such as salts of fatty acids, may modify the properties of arginase in vivo.

However, the existence of subunits is not a necessary indication of regulation. Subunits provide stability, the conservation of DNA, and lessen the chance of a lethal mutation; many nonregulatory enzymes are composed of several subunits (Monod, 1969). 
Archibald, R.M. (1945) Colorimetric determination of urea. J. Biol. Chem. 157, 507-518.

Baret, R., Girard, C. and Riou, J. (1972) Sur certaines propriétés des arginases du tissu hepatopancréatique d'Helix pomatia Lin. et d'Helix aspersa Mül1. Biochimie 54, 421-430.

Bishop, S.H. and Campbell, J.W. (1965) Arginine and urea biosynthesis in the earthworm Lumbricus terrestris. Comp. Biochem. Physiol. 15, $51-71$.

Brown, G.W., Jr. and Cohen, P.R. (1959) Comparative biochemistry of urea synthesis $I$. Methods for the quantitative assay of urea cycle enzymes in 1iver. J. Biol. Chem. 234, 1769-1774.

Brown, G.W., Jr. (1966) Studies in comparative biochemistry and evolution. Archs. Biochem. Biophys. 114, 184-194.

Cabello, J. (1967) Discussion: enzymatic aspects of metabolic regulation. U.. S. Nat. Cancer Inst. Nonograph 27, 297-298.

Campbell, J.W. (1966) A comparative study of molluscan and mammalian arginases. Comp. Biochem. Phys1o1. 18, 179-199.

Canedo, L., Martuscelli, J. and Mora, J. (1967) Catabolism of L-arginine in Neurospora crassa. U.S. Nat. Cancer Inst. Monograph 27, 273-283.

Carlisky, N.J. and Sadnik, I.L. (1972) Properties of amphibian renal arginase $I$. The effect of dialysis and sulfhydryl compounds. Comp. Biochem. Physiol. 41B, 785-792.

Clementi, A. (1937) L'arginase epatica I. Suoi rapporti con a genesi dell'urea durante $1^{\prime}$ autolisi del fegato nella serfe def vertebrati. Enzymologia 4, 205-216.

Cvancara, V.A. (1971) Liver arginase activity in the sockeye salmon, Oncorhynchus nerka. Comp. Biochem. Physiol. 40B, 819-822.

Davis, B.J. (1964) Disc electrophoresis, methods and applications to human serum proteins. Ann. N. . . Acad. Sci. 121, 404-427.

Fawcett, J.K. and Scott, J.E. (1960) A rapid and precise method for the determination of urea. J. Ciin. Path. 13, 156-159.

Gerhart, J.C. and Pardee, G.B. (1962) The enzymology of control by feedback inhibition. J. Biol. Chem. 237, 891-896. 
Greenberg, D.M. and Mohamed M.S. (1945) Liver arginase II. Kinetic properties. Archs. Biochem. 8, 365-375.

Greenberg, D.M., Bagot, A.E. and Roholt, O.A., Jr. (1956) Liver arginase III. Properties of highly purified arginase. Archs. Biochem. Biophys. $62,446-453$.

Greenberg, D.M. (1960) Arginase. (in) The Enzymes (edited by Boyer, P., Lardy, H. and Myrback, K.) 2nd edn, vol. 4, 257-267. Academic Press, New York.

Hartenstein, R. (1971) Characteristics of arginase from the freshwater crayfish Cambarus bartoni. Comp. Biochem. Physiol. 40B, 781-795.

Hirsch-Ko1b, H. and Greenberg, D.M. (1968) Molecular characteristics of rat liver arginase. J. Biol. Chem. 243, 6123-6129.

Hirsch-Kolb, H., Heine, J.P., Kolb, H.J. and Greenberg, D.M. (1970) Comparative physical-chemical studies of mammalian arginases. Comp. Biochem. Physiol. 37, 345-359.

Hirsch-Kolb, H., Kolb, H.J. and Greenberg, D.M. (1971) Nuclear magnetic resonance studies of manganese binding of rat liver arhinase. J. Biol. Chem. 246, 395-401.

Hochachka, P.W. and Mustafa, T. (1973) Enzymes in facultative anaerobis of molluscs I. Malic enzyme of oyster adductor muscle. Comp. Biochem. Physio1. 45B, 625,637.

Hult, J.E. (1969) Nitrogenous waste products and excretory enzymes in the marlne polychaete Cirriformia spirabranchia (Moore). Comp. Biochem. Physto1. 31, 15-24.

Khramov, V.A. and Galaev, Y.V. (1971) Rasprostranenie arginazy u mikrobov. Lab. De1o. 1, 50-53.

Klotz, I.M. (1967) Protein subunits: a table. Science 155, 697-698.

Laverack, M.S. (1963) The Physlology of Earthworms. Macmillan, New York.

Linn, S. and Lehmann, I.R. (1965) An endonuclease from Neurospora crassa specific for polynucleotides lacking an ordered structure. J. Biol. Chem. 240, 1287-1293.

Lowry, O.H., Rosebrough, N.J., Fair, A.L. and Randa11, R.J. (1951) Protein measurement with the Folin phenol reagent. J. Biol. Chem. 193, 265-275.

Mepham, T.B. and Linze11, J.L. (1966) A quantitative assessment of the contribution of individual plasma amino acids to the synthes is of milk proteins by the goat mamary gland. Biochem. J. 101, 76-83. 
Middlehoven, W.J. (1969) The ferrous ion as the cofactor of arginase in vivo I. Properties of yeast arginase metallocomplexes of known composition and of native arginase. Biochem. Biophys. Acta 118, 206209.

Monod, J., Changeux, J.P. and Jacob, F. (1963) Allosteric proteins and cellular control systems. J. Mol. Biol. 6, 306-329.

Monod, J. (1969) On symmetry and function in biological systems. (in) 11 th Nobel Symposium (edited by Engstrom, A. and Stranberg, B.) 1527. Wiley Interscience Press, New York.

Mora, J., Tarrab, R., Martusce11i, J. and Soberón, G. (1965) Characteristics of arginases from ureotelic and non-ureotelic animals. Biochem. J. 96, 588-594.

Mora, J., Tarrab, R. and Bojalil, L.F. (1966) On the structure and function of different arginases. Biochem. Biophys. Acta 118, 206209.

Needham, A.E. (1957) Components of nitrogenous excreta in the earthworms Lumbricus terrestris L. and Eisenia foetida (Savigny). J. Exp. Biol. 34, 425-446.

Needham, A.E. (1960) The arginase activity of the tissues of the earthworms Lumbricus terrestris L. and Eisenia foetida (Savigny). J. Exp. Biol. 37, 775-782.

Needham, A.E. (1962) Distribution of arginase activity along the body of earthworms. Comp. Biochem. Physiol. 5, 69-82.

Reddy, S.R.R. and Campbe11, J.W. (1968) A low molecular weight arginase in the earthworm. Blochem. Biophys. Acta 159, 557-560.

Reddy, S.R.R. and Campbell, J.W. (1969a) Arginine metabolism in insects: properties of insect fat body arginase. Comp. Blochem. Physiol. 28, 515-534.

Reddy, S.R.R. and Campbell, J.W. (1969b) Arginine metabolism in insects: role of arginase in proline formation during silkmoth development. Blochem. J. 115, 495-503.

Reddy, S.R.R. and Campbell, J.W. (1970) Molecular weights of arginase from different species. Comp. Blochem. Physiol. 32, 499-509.

Rogers, S. and Moore, M. (1963) Studies of the mechanism of action of the Shope rabbit papilloma virus I. Concerning the nature of the induction of arginase in the infected cells. J. Exp. Med. 117, 521545. 
Rossi, N. and Grazi, G. (1969) Characterization of a new type of arginase from chicken liver. Eur. J. Biochem. 7, 348-352.

Schimke, R.T. (1962) Adaptive characteristics of urea cycle enzymes in the rat. J. Biol. Chem. 237, 459-468.

Soberón, G., Ortiz-Pineda, J. and Tarrab, R. (1967) Characteristics of the ureotelic arginase and its role in the advent of ureotelism during metamorphosis of the Mexican axolot1. U.. . Nat. Cancer Inst. Monograph 27, 283-295.

Soru, E. (1965) Purification of bacterial arginase. J. Chromatography $20,325-333$.

Tabor, H. and Tabor, C.W. (1969) Partial separation of two pools of arginine in E. colf; preferential use of exogenous rather than endogenous arginine for the biosynthesis of 1,4 diamino butane. J. B1ol. Chem. 244, 6383-6387.

Ternberg, J.L. and Hershey, F.B. (1964) Colorimetric determination of blood ammonia. J. Lab. Clin. Med. 56, 766-776.

Vielle-Breltburd, F. and Orth, G. (1972) Rabbit liver L-arginase: purification, properties, and subunit structure. J. Biol. Chem. 247, 1227-1235.

Y1p, M.C.M. and Knox, W.E. (1972) Function of arginase in lactating mammary gland. Blochem. J. 127, 893-899. 